\title{
Plug Source and Growth Retardants Affect Finish Size of Bedding Plants
}

\author{
Jeff S. Kuehny ${ }^{1}$, Aaron Painter ${ }^{2}$, and Patricia C. Branch ${ }^{3}$ \\ Department of Horticulture, Louisiana State University Agricultural Center, \\ Louisiana Agricultural Experiment Station, 137 Julian C. Miller Hall, \\ Baton Rouge, LA 70803-2120 \\ Additional index words. bedding plants, plant growth regulators, Dianthus chinensis, \\ Petunia $\times$ hybrida, Viola $\times$ wittrockiana, Antirrhinum majus, Matthiola incana, \\ Catharanthus roseus, Salvia splendens, Begonia $\times$ semperflorens-cultorum
}

\begin{abstract}
Eight bedding plant species were grown from plugs obtained from two sources. The plugs were transplanted into jumbo six packs and sprayed with a solution of chlormequat/daminozide with concentrations of $1000 / 800,1250 / 1250$, or 1500/5000 $\mathrm{mg} \cdot \mathrm{L}^{-1}$ when new growth was $\approx 5 \mathrm{~cm}$ in height or width. Three different species were grown in the fall (Dianthus chinensis L., 'Telstar Mix', Petunia Xhybrida Hort. Vilm.Andr., 'Dreams Red', and Viola Xwittrockiana Gams., 'Bingo Blue'), winter [Antirrhinum majus L., 'Tahiti Mix', Matthiola incana (L.) R. Br., 'Midget Red', and $P$. $\times$ hybrida, 'Dreams Mix'], and spring [Catharanthus roseus (L.) G. Don, 'Cooler Pink', Salvia splendens F. Sellow ex Roem. \& Schult., 'Empire Red', and Begonia Xsemperflorenscultorum Hort., 'Cocktail Mix']. The treatments significantly reduced finished plant size of all species for each season. There was a significant difference in finish size between sources for Dianthus, Antirrhinum, Matthiola, Catharanthus, Salvia, and Begonia. The efficacy of chlormequat/daminozide also differed for each source of Dianthus, Matthiola, and Begonia, but the treatments minimized the differences in finish size between sources for Petunia and Viola. Chemical names used: (2-chlorethyl) trimethylammonium chloride (chlormequat); $(N$-dimethylaminosuccinamic acid) (daminozide).
\end{abstract}

Plant growth retardants (PGRs) are of particular importance in the southern United States, where environmental control is more difficult and often not an effective method for regulating plant height (Kuehny et al., 1997). Use of PGRs reduces internode length (Barrett et al., 1994), resulting in smaller plants that are better for shipping and customer satisfaction.

Plug production has increased the finished product's quality and uniformity, and legitimized bedding plants as profitable items (Armitage and Kaczperski, 1994). Various methods of height control are used in plug production. Some plug growers may control height by monitoring the difference between day and night temperatures $($ day - night $=$ DIF) (Erwin et. al., 1989), while others achieve better results with chemicals (Barrett et al., 1994). In certain situations, a combination of DIF and PGRs is used to control plant height

Received for publication 20 Nov. 1998. Accepted for publication 26 June 2000. Louisiana Agricultural Experiment Station manuscript no. 98-28-0545. We would like to thank the Louisiana Association of Nurserymen for supporting this research. We would also like to acknowledge Ball Seed Co., BASF/ Olympic Chemical and Uniroyal Chemical for providing material for this research. The cost of publishing this paper was defrayed in part by the payment of page charges. Under postal regulations, this paper therefore must be hereby marked advertisement solely to indicate this fact.

'Associate Professor. E-mail address: jkuehny@ lsu.edu

${ }^{2}$ Undergraduate Student.

${ }^{3}$ Research Associate. of plugs (Fisher and Heins, 1998). Factors such as time of application, environmental conditions, and mode of action determine extent and duration of effectiveness (Styer, 1997). The wide range of cultural practices used to grow plugs could also influence the efficacy of PGRs applied to the same crop in finishing. A bedding plant grower who purchases plugs from different sources should be aware that cultural practices may influence plug performance in transplant or later stages of production.

Extensive information is available concerning recommended PGRs and concentrations for specific bedding plants (Ball, 1998; Barrett et al., 1994; Barrett and Nell, 1992; Cox and Keever, 1988; Kuehny et al., 1997; Starman et al., 1994); however, these recommendations do not always account for different seasonal growing temperatures, irradiance, and photoperiods (and resulting changes in PGR application that must be used by some growers). In addition, no studies have been conducted on how differing cultural practices used in plug production influence final plant size and PGR efficacy during finishing. The objective of this research was to determine the effect of chlormequat + daminozide spray applications on development of bedding plant species from two plug sources.

\section{Materials and Methods}

Bedding plant plugs were planted in three experiments; three species were grown in the fall (Expt. 1, planted 3 Nov. 1997) (Dianthus chinensis L., 'Telstar Mix', Petunia $\times$ hybrida Hort. Vilm.-Andr., 'Dreams Red', and Viola $\times$ wittrockiana Gams., 'Bingo Blue'), winter (Expt. 2, planted 25 Feb. 1998) [Antirrhinum majus L., 'Tahiti Mix', Matthiola incana (L.) R. Br., 'Midget Red', and P. ×hybrida, 'Dreams Mix'], and spring (Expt. 3, planted 24 Apr. 1998) [Catharanthus roseus (L.) G. Don, 'Cooler Pink', Salvia splendens, 'Empire Red', and Begonia $\times$ semperflorens-cultorum Hort., 'Cocktail Mix']. The 288-cell plug trays $\left(6.1 \mathrm{~cm}^{3}\right.$ per cell) were obtained from two sources designated as source 1 and source 2 . Differences between source 1 and source 2 production methods were PGR used, PGR rates, frequency of application, greenhouse temperatures and fertilization. These are not provided here, as the techniques used are proprietary. Each species was planted in jumbo six packs $\left(180 \mathrm{~cm}^{3}\right.$ per cell) in Metro Mix 250 (Scotts Co., Marysville, Ohio). Plants were fertilized at each irrigation with $20 \mathrm{~N}-$ 4.4P-16.6K (20-10-20 Peat-lite special; Scotts Co.) at $150 \mathrm{mg} \cdot \mathrm{L}^{-1} \mathrm{~N}$ until PGRs were applied, and with $250 \mathrm{mg} \cdot \mathrm{L}^{-1} \mathrm{~N}$ following the application of PGRs. Average maximum daytime/minimum nighttime greenhouse temperatures were $28 / 24{ }^{\circ} \mathrm{C}$ (fall), $31 / 21{ }^{\circ} \mathrm{C}$ (winter), and $34 / 28^{\circ} \mathrm{C}$ (spring).

A chlormequat/daminozide tank mix was applied at $0,1000 / 800,1250 / 1250$, and 1500/ $5000 \mathrm{mg} \cdot \mathrm{L}^{-1}$, respectively, as a one-time foliar spray to drip, when new plug growth was $\approx 5$ $\mathrm{cm}$ in height or width. Control plants were sprayed with water only. Applications were made 10,13 , and $7 \mathrm{~d}$ after planting for the fall, winter and spring experiments, respectively.

Height and diameter (average of two measurements perpendicular to one another) of each plant were measured. Plant size (sum of average height plus average diameter) was determined at $50 \%$ bloom [32 and 33 d for Petunia (spring and winter experiments), $35 \mathrm{~d}$ for Viola, 39 d for Dianthus, 33 d for Petunia, $40 \mathrm{~d}$ for Antirrhinum, $42 \mathrm{~d}$ for Matthiola, $16 \mathrm{~d}$ for Salvia, $22 \mathrm{~d}$ for Catharanthus, and $28 \mathrm{~d}$ for Begonia].

Each experiment was arranged in a completely randomized design with four treatments, each of which was applied to a total of six jumbo six packs, with each six pack constituting an experimental unit. Analysis of variance (ANOVA) and orthogonal polynomial contrasts were used for data analysis (General linear model, SAS, 1987; SAS Institute, Cary, N.C.).

\section{Results}

Plant size decreased linearly as concentrations of chlormequat/daminozide increased in all species and experiments (Figs. 1-3). Source 2 Dianthus plants were significantly larger than source 1 plants (up to $21 \%$ larger for the fall experiment) (Fig. 1A and Table 1). The significant interaction of treatment and source of Dianthus indicates that the efficacy of chlormequat + daminozide varied with source. There was no affect of source on growth of Petunia and Viola, and no interaction of source with treatment (Fig. 1 B and C; 
Table 1). Source 2 Antirrhinum and Matthiola plants were also significantly larger than source 1 plants (up to $20 \%$ and $24 \%$, respectively) and the efficacy of chlormequat/ daminozide differed with source of Matthiola in the winter experiment (Fig. 2 A and B; Table 1). There was no effect of source on growth of Petunia (Fig. 2C and Table 1), nor was source $\times$ treatment interaction signifi-

Table 1. ANOVA of experiments to determine effects of chlormequat/daminozide and plug source on bedding plant size.

\begin{tabular}{|c|c|c|c|c|}
\hline Experiment & Species & $\begin{array}{l}\text { Chlormequat/ } \\
\text { Daminozide }\end{array}$ & $\begin{array}{c}\text { Plug } \\
\text { source }\end{array}$ & $\begin{array}{c}\text { Chlormequat }+ \\
\text { Daminozide } \times \text { Plug Source }\end{array}$ \\
\hline Fall & Dianthus chinensis & $* * *$ & $* * *$ & $* *$ \\
\hline Fall & Petunia $\times$ hybrida & $* * *$ & NS & NS \\
\hline Fall & Viola $\times$ wittrockiana & $* * *$ & NS & NS \\
\hline Winter & Antirrhinum majus & $* * *$ & $* * *$ & NS \\
\hline Winter & Matthiola incana & $* * *$ & $* * *$ & $* *$ \\
\hline Winter & Petunia $\times$ hybrida & $* * *$ & NS & NS \\
\hline Spring & Catharanthus roseus & $* * *$ & $* * *$ & NS \\
\hline Spring & Salvia splendens & $* * *$ & $* * *$ & NS \\
\hline Spring & Begonia $\times$ semperflorens-cultorum & $* * *$ & $* * *$ & $*$ \\
\hline
\end{tabular}

$\overline{\text { Ns, }, * * *, * * *}$ Nonsignificant or significant at $P \leq 0.05,0.01$, or 0.001 , respectively.

cant. Source 2 Catharanthus and Begonia plants were significantly larger than source 1 plants in the spring experiment, and interaction between treatment and source was significant in Begonia (Fig. $3 \mathrm{~A}$ and C; Table 1). Source 1 Salvia plants were up to $13 \%$ larger than source 2 plants; this was the only species where this was the case (Fig. 3B and Table 1).
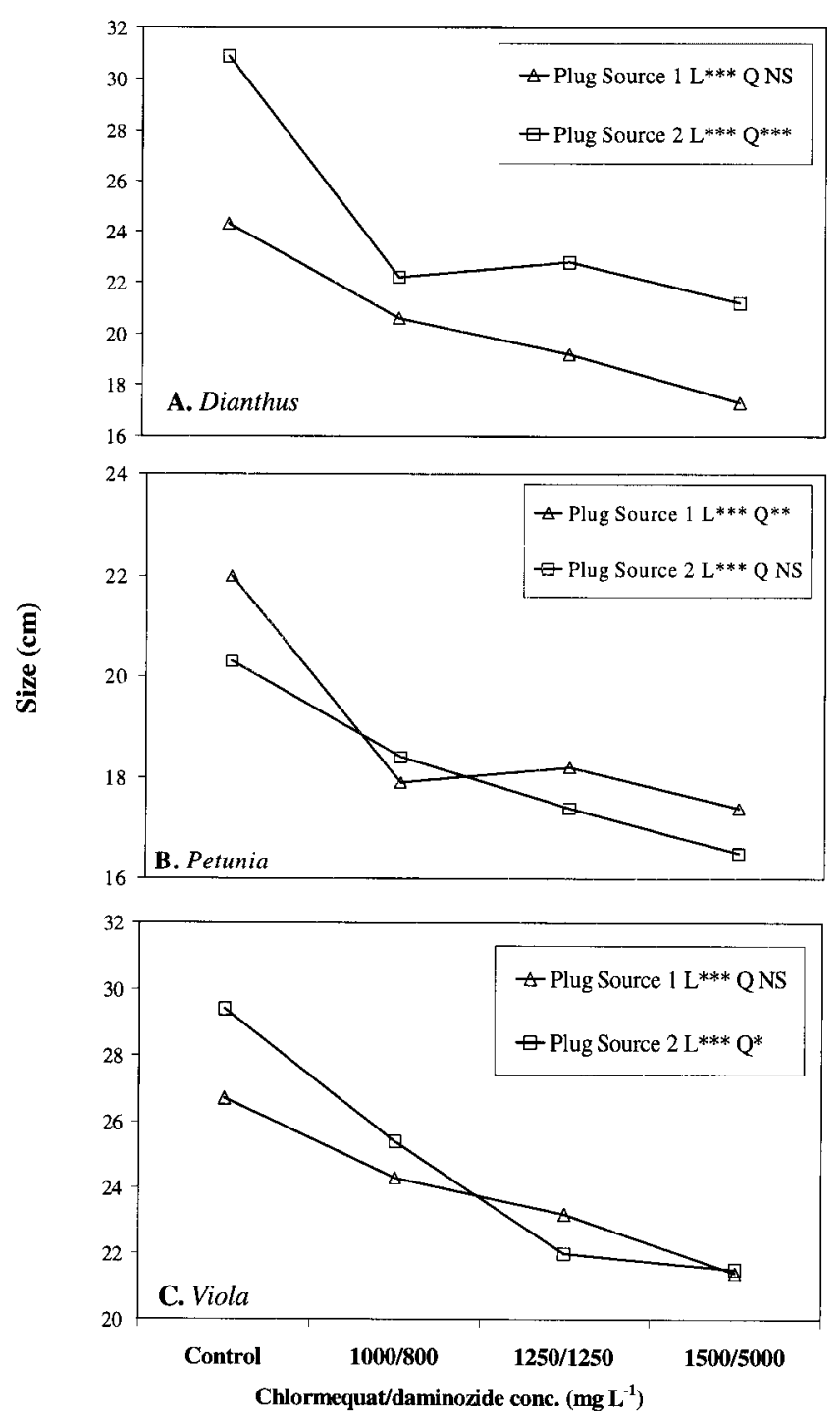

Fig. 1. Effects of chlormequat/daminozide concentration $\left(\mathrm{mg} \cdot \mathrm{L}^{-1}\right)$ on size $(\mathrm{cm})$ (sum of average height plus average diameter). ${ }^{\mathrm{ss},},{ }^{*}, *, * * * *$ Nonsignificant or significant at $P \leq 0.05,0.01$, or 0.001 , respectively. $\mathrm{L}=$ linear and $\mathrm{Q}=$ quadratic. $\mathrm{Q}=$ quadratic.

\section{Discussion}

Variations occurred in finished bedding plant size when grown from plugs obtained from two sources. Differences in cultural practices used to grow these plugs involved PGR use, PGR rates, frequency of application, greenhouse temperatures, and fertilization. These variations in cultural practices significantly influenced the size of the finished bedding plant and the efficacy of PGR concentration (Fig. 1A-C; Table 1). The plants from source 2 were significantly larger than those from source 1 in every experiment, except for Salvia in the spring experiment (Fig. 3B).

Plant growth retardants minimized the size variation among plants from different sources for certain species. The resulting sizes of Petunia (fall and winter experiment) and Viola (fall experiment) indicate that source differences in plant size can be reduced and a more uniform crop can be produced by using PGRs (Figs. $1 \mathrm{~B}$ and C; 2C).
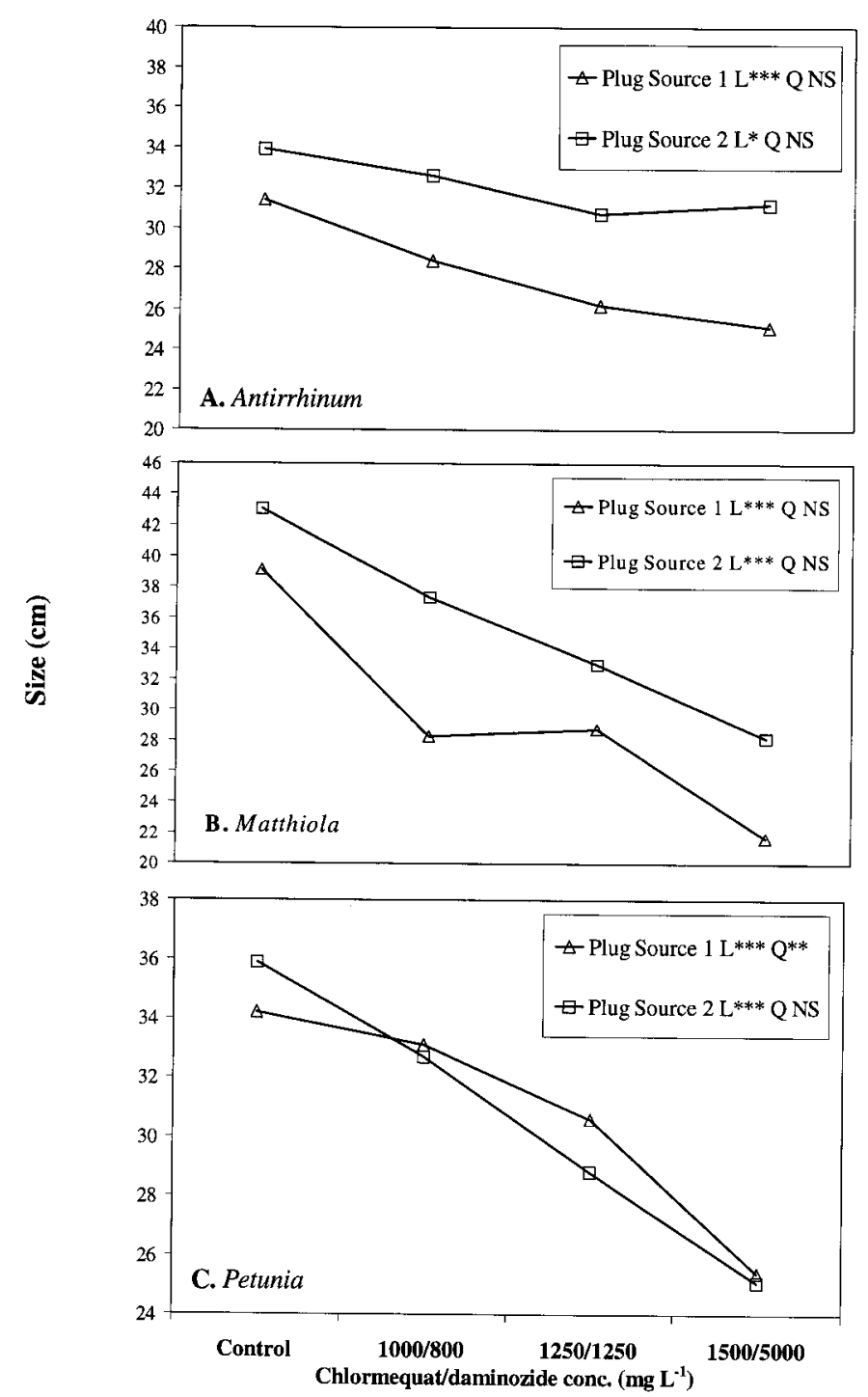

Fig. 2. Effects of chlormequat/daminozide concentration $\left(\mathrm{mg} \cdot \mathrm{L}^{-1}\right)$ on size $(\mathrm{cm})$ (sum of average height plus average diameter). ${ }^{\text {s, }, * *, * * * *}$ Nonsignificant or significant at $P \leq 0.05,0.01$, or 0.001 , respectively. $\mathrm{L}=$ linear and 
The efficacy of a PGR used to control finished bedding plant size can be affected by many factors. These include greenhouse temperatures (Fisher and Heins, 1998), time of day applied (Kuehny et al., 1997), size of plant at application (Gilbertz, 1992), number of applications (Miranda and Carlson, 1980), volume of application (Barrett et al., 1994), improper application of PGR (Styer, 1997), and the rate of PGR applied (Barret and Erwin, 1994). These factors can be controlled by the producer of both the bedding plant plugs and finished bedding plants.

Effect of source (plugs grown at different

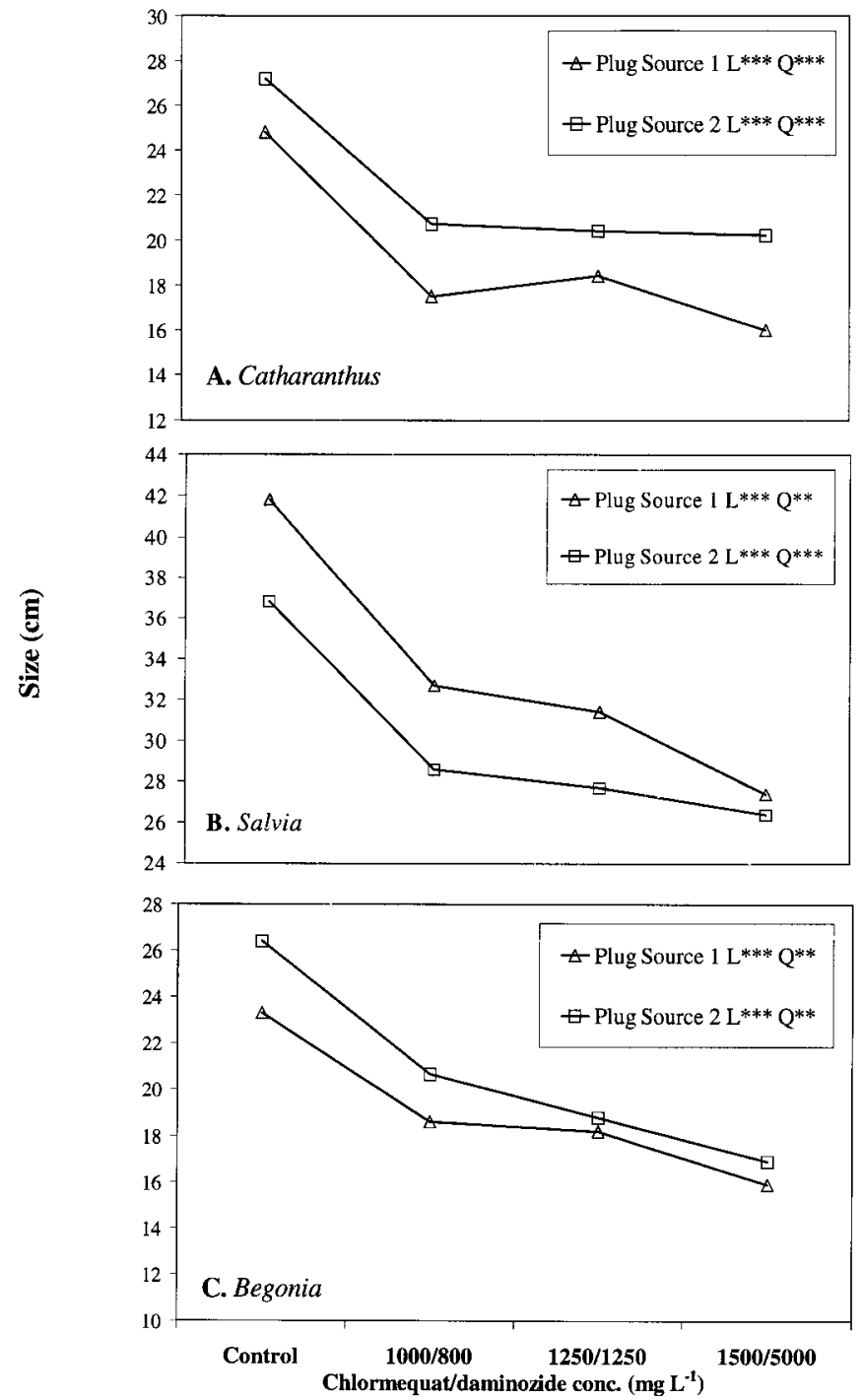

Fig. 3. Effects of chlormequat/daminozide concentration $\left(\mathrm{mg} \cdot \mathrm{L}^{-1}\right)$ on size $(\mathrm{cm})$ (sum of average height plus average diameter). ${ }^{\mathrm{Ns}, *, * *, * * *}$ Nonsignificant or significant at $P \leq 0.05,0.01$, or 0.001 , respectively. $\mathrm{L}=$ linear and $\mathrm{Q}=$ quadratic. locations and with different cultural practices) has been suggested as being responsible for some of the differences found in finished plant size. This research confirms that hypothesis and indicates that further research should be conducted to determine the effect of the different cultural practices and environmental conditions on bedding plant plug production and the resultant effect on finished bedding plants.

\section{Literature Cited}

Armitage, A.M. and M.P. Kaczperski. 1994. Traditional versus plug production, p. 113-126. In: E.J. Holcomb (ed.). Bedding plants IV. Ball Publishing, Batavia, Ill.

Ball, V. 1998. Bedding plants: Trends and seed basics, p. 201-234. In: Vic Ball (ed.). Ball RedBook, $16^{\text {th }}$ ed. Ball Publishing, Batavia, Ill. Barrett, J.E., C.A. Bartuska, and T.A. Nell. 1994. Application techniques alter uniconazole efficacy on chrysanthemums. HortScience 29:893-895.

Barrett, J.E. and J.E. Erwin. 1994. Bedding plant height control, p. 197-214. In: E.J. Holcomb (ed.). Bedding Plants IV. Ball Publishing, Batavia, Ill.

Barrett, J.E. and T.A. Nell. 1992. Efficacy of paclobutrazol and uniconazole on four bedding plant species. HortScience 27:896-897.

Cox, D.A. and G.J. Keever. 1988. Paclobutrazol inhibits growth of zinnia and geranium. HortScience 23:1029-1030.

Erwin, J.E., R.D. Heins, and M.G. Karlsson. 1989. Thermomorphogenesis in Lilium longiflorum. Amer. J. Bot. 76:47-52.

Fisher, P. and R. Heins. 1998. DIF and graphical tracking, p. 303-316. In: Vic Ball (ed.). Ball RedBook, $16^{\text {th }}$ ed., Ball Publishing, Batavia, Ill.

Gilbertz, D.A. 1992. Chrysanthemum response to timing of paclobutrazol and uniconazole sprays. HortScience 27:322-323.

Kuehny, J.S., A. Owings, and B. Morales. 1997. Bedding plant production guide for Louisiana. La. State Univ. Agr. Ctr., Baton Rouge.

Miranda, R.M. and W.H. Carlson. 1980. Effect of timing and number of applications of chlormequat and ancymidol on the growth and flowering of seed geraniums. J. Amer. Soc. Hort. Sci. 105:273-277.

Starman, T.W., T.A. Cerny, and T.L. Grindstaff. 1994. Seed geranium growth and flowering responses to uniconazole. HortScience 29:865867.

Styer, R.C. 1997. Putting the brakes on plug growth. Grower Talks 61(7):40-45. 